The Canadian Journal of Higher Education La revue canadienne d'enseignement supérieur

Volume XXX, No. 2, 2000 pages 123-142

\title{
Experiences at University: Perceptions of students with disabilities
}

\section{CHERYLL DUQUETTE}

University of Ottawa

\section{ABSTRACT}

Using Tinto's (1975) model of dropping out or persisting, this study examined the perceived experiences at university of students with disabilities. Tinto's (1975) model presents three variables which are related to persistence: background characteristics, integration into the academic milieu, and social integration. Thirty-six students completed a questionnaire, and of this group 17 participated in a narrative interview. Later, six of these people engaged in a focus group. The findings of this study showed that background characteristics and academic integration were more important variables related to persistence than social integration. Goal commitment, support of family and friends and understanding professors were found to be important elements related to persisting among these students with disabilities.

\section{RÉSUMÉ}

En employant le modèle de Tinto (1975) relatif au décrochage ou à la persistance scolaire, cette étude examine d'étudiant(e)s handicapés quant à leurs expériences universitairies. Le modèle de Tinto (1975) présente trois variables en lien avec la persistance: le cadre de vie,

* The author would like to acknowledge the support of the Canadian Council for Exceptional Children in this research project. 
l'intégration scolaire et l'intégration sociale. Trente-six étudiantes et étudiants ont rempli un questionnaire et, de ce groupe, 17 ont pris part à une entrevue individuelle. Par la suite, six de ces personnes ont participé a un groupe de discussion. Les résultats de cette étude démontrent que le cadre de vie et l'intégration scolaire sont des variables plus importantes que l'integration sociale en ce qui concerne la persistance scolaire. L'engagement face au but, le soutien de la famille et des amis ainsi que des professeurs compréhensifs se sont averés des éléments imiportants reliés à la persistance de ces étudiant(e)s handicapés.

Over ten years ago, Marc Wilchesky (1986) predicted an increase in the number of person with disabilities attending Canadian universities. He reported that the passage of Ontario's Bill 82, An Act to Amend the Education Act (1980) (now superceded by Bill 160) and Section 15 of the Canadian Charter of Rights and Freedoms as set out in The Constitution Act of 1982, enacted in 1985, would drive such an increase. Essentially, people with disabilities could not be excluded from post secondary institutions on the basis of their disability. Wilchesky (1986) also raised important issues on the inclusion of students with disabilities: architectural barriers, attitudinal problems of university personnel, the need for fair and accurate assessment, and the requirement of support for students coping with the demands of higher education.

How far have we come in addressing the needs of students with disabilities attending Canadian universities? Hill (1992) surveyed the Offices for Students with Disabilities at 27 Canadian universities to ascertain the types of services provided to students with disabilities. She reported that both small and large institutions are attempting to accommodate students with special needs. A wide variety of services are available to students and the university community, the most common being general advising. Larger postsecondary institutions in Canada offer more services and employ more support service workers than do smaller universities. However, the ratio of types of services to number of students, and ratio of number of employees to total enrolment are comparable (pp. 72-73). Hill also commented that problems persist in the following 
areas: (a) identifying those students who require special services; (b) making students aware of the services; and (c) developing fair and equitable admissions policies. Cox and Klas (1996) reported that in Canadian universities attitudinal problems and a general lack of understanding by some faculty and administrators continues. They further state that accommodations for people with disabilities are designed to provide equal opportunity, and that adjustments for them do not jeopardize excellence.

Although a body of research on the type and range of academic support provided to students with disabilities attending Canadian universities is developing, it is not yet known if these services are meeting the needs of those students. Moreover, there is no information on the sources of social support and the personal characteristics of this group of students. In sum, research to date does very little to inform the university community about the needs and experiences of the students with disabilities.

\section{TINTO ‘S (1975) MODEL OF DROPOUT}

Integration into university life and successful completion of one's studies are goals not easily attained by all students. Siperstein (1988) posits that for students with disabilities who are entering a post secondary institution, maintaining one's status and graduating can present huge, on-going problems. Therefore if the path to graduation is difficult for nondisabled students, it is even harder for students with disabilities. Tinto (1975) theorizes that the process of dropping out from college can be viewed as a longitudinal one in which the interactions between the individual and the academic and social systems of the college continually modify his or her goal and institutional commitments in ways which lead to persistence and/or to varying forms of dropout (p. 94).

Tinto (1975) developed a model of dropping out that presents three variables which help to explain the phenomena of dropping out and persisting. The first variable is background characteristics. The variable encompasses personal attributes (e.g., sex, race, ability), previous experiences, and family situations. Tinto (1975) theorizes that each of these elements has an impact on performance in university or college. More importantly, these background characteristics and individual attributes also influence educational expectations and commitments. Tinto (1975) 
further argues that given these educational goals and commitments, it is the student's integration into the academic and social systems of the institution that most directly relate to dropping out or persisting. Hence, the second variable is integration into the academic milieu, which refers to the student's grade performance and his or her intellectual development during the postsecondary years. The third variable is social integration, which occurs through informal peer group associations, semi-formal extracurricular activities, and interaction with faculty and administrative personnel within the institution. In sum, the higher the degree of integration of the individual into the institution, the greater will be his or her commitment to the specific institution and to the goal of graduation. Therefore, it is the interplay between the three variables of (a) background characteristics and attributes determining the level of goal commitment, (b) level of institutional integration, and (c) level of social integration that determine whether or not a student will graduate.

\section{THE PROBLEM}

McKeown, MacDonell and Bowman (1993) recommend that researchers ought to study the matter of attrition/persistence from the perspective of the students themselves in order to learn of the personal experiences of students. At this point there have been no studies in which students with disabilities have presented their perspectives of life at university. Much of the research from the United States focuses on descriptions of the need for transition programs and the services that are available at postsecondary institutions. A close examination of the Canadian literature shows a similar pattern. There is a need to know about the experiences of students with disabilities and how they view university life. There is also a need to know the extent to which they feel socially and academically integrated into the institution, as well as their individual characteristics. Tinto's (1975) model is useful for gathering information on these three variables, and shedding light on the persisting or dropping out behaviours of students with disabilities.

The purpose of this research, therefore, was to investigate the experiences of post secondary students with disabilities using Tinto's (1975) model of dropout. The research questions were as follows: 
1. What are the individual characteristics of students with disabilities?

2. To what extent are these students integrated into the academic milieu?

3. To what extent are students with disabilities integrated into the social milieu?

\section{METHOD}

Tinto's (1975) three domains (background characteristics, academic integration, and social integration) were explored using methodological procedures for conducting qualitative research as outlined by Miles and Huberman (1984). The study involved three overlapping arenas of data collection and analysis. The initial group consisted of 131 Englishspeaking students who had registered at the Centre for Special Services, of which only 36 students participated (27\%). Although it is a low rate of return, this number appears to be representative of the proportion of people who make use of the services. Vogel and Adelman (1992) state that many factors influence students' decisions to use or not to use services for disabled students. The person may not recognize the need to use them or, having recognized the need, may not know how to access the available services. Self-understanding, prior experience and reality testing, level of acceptance and denial, availability and quality of intervention, developmental life stage, motivation and goals are some of the factors that enter into the complex decision to acknowledge one's disability and to seek out support services.

Surveys consisting of open-ended questions were sent to the Englishspeaking students registered at the Centre for Special Services at a large university in Ontario (see Table 1 for a description of the sample). The purpose of the questionnaire was to obtain information in the domains of individual characteristics, personal support systems, and institutional accommodations. The second strategy for data collection involved narrative interviews with 17 students, in which the guidelines outlined by LeCompte and Preissle (1993) were followed. The audio-taped interviews consisted of standardized open-ended questions that focused on the 
Table 1

Distribution of Gender According to Disability $(n=36)$

\begin{tabular}{l|c|c|c|c|c|c|c}
\hline & $\begin{array}{c}\text { Medical } \\
\text { Disability }\end{array}$ & $\begin{array}{c}\text { Learning } \\
\text { Disability }\end{array}$ & $\begin{array}{c}\text { Physical } \\
\text { Disability }\end{array}$ & $\begin{array}{c}\text { Hearing } \\
\text { Impairment }\end{array}$ & $\begin{array}{c}\text { Visual } \\
\text { Impaiment }\end{array}$ & $\begin{array}{c}\text { Multiple } \\
\text { Disabilities }\end{array}$ & Total \\
\hline Male & 5 & 2 & 1 & 0 & 0 & 1 & 9 \\
\hline Female & 12 & 6 & 1 & 3 & 4 & 1 & 27 \\
\hline Total & 17 & 8 & 2 & 3 & 4 & 2 & 36 \\
\hline
\end{tabular}

three domains as well as the specific experiences of the students during their university careers. The purpose of these interviews was to permit participants the opportunity to express their experiences and perceptions. The third arena of data collection was a focus group consisting of six of the 17 students who had been interviewed. Following the guidelines provided by Morgan (1988), a set of questions was asked of the group, and the entire interview was audio-taped. The purpose of the focus group was to explore themes from the questionnaire and the individual interviews.

Using the data from the questionnaires and the transcripts of interviews, data were coded using symbols and categorized according to the questions that were asked (Miles \& Huberman, 1984). The categories were examined for similarities and differences. Themes emerged from these categories. The trustworthiness of the findings was established through thick description, triangulation, and member checks (LeCompte \& Preissle, 1993; Lincoln \& Guba , 1985).

\section{FINDINGS}

\section{Individual Characteristics}

Of the 36 students who returned the questionnaire, 27 were female and 9 were male. From that group, 17 volunteered to participate in an individual interview. This sub-group consisted of 14 females and 3 males. The focus group involved four females and two males. In this 
study, there were a higher proportion of female to male respondents for all three phases of the research. The students came from a variety of racial, ethnic, and socio-economic backgrounds. All but one student completed his or her elementary and secondary schooling in Canada. Only three had been placed in special schools or classrooms (two with visual impairment and one with a learning disability). The remaining students had been integrated into regular classrooms and had followed the usual elementary and secondary programs with little or no academic support or accommodations.

The students described themselves as persistent, goal-oriented, resourceful/creative, determined people, who enjoyed learning. One student with a learning disability wrote, "I have goals and dreams like everyone does, and I intend to pursue them the best way I can." Another person commented, "I am a very persistent and stubborn person. If I want something bad enough, I don't let anything stand in my way. And I won't give up until my goal is accomplished. I am also patient and if something doesn't work for me one way, I'll try another." A third respondent stated, "I work very hard, and I don't quit." The responses from the students indicated that they are committed to achieving their goal of completing their program and of graduating. For some of the students the goal was simply to graduate. For others, however the degree was a step towards a career and financial security.

\section{Academic Integration}

All of the students reported a feeling of being equal to the intellectual challenge offered by university studies. However, some of them expressed the observation that they had to spend more time on their studies in order to achieve satisfactory marks. One student with a learning disability stated, "I just know that I do double the time for work I get back." She also stated that in her program she is forced to do the things that are not her strengths (reading). She further said that she is not very comfortable in the academic milieu as a result. Another person with a medical disability reported, "It may take me $11 / 2$ times as long to do something, but I do it right." To accommodate the extra time required to complete the work, some of the students have chosen to study part-time. 
A student with many medical problems stated, "It doesn't matter how long it takes [to earn the degree], it matters whether you get it."

Despite the struggles, some of the students expressed their enjoyment of learning. One student wrote, "Finally finding something I'm good at academically makes the struggle worth while." Another student with a medical disability stated, "I love what I'm doing...it's everything for me just to sit and read, and study...And, I think it makes a big difference when you're doing something because you love doing it." These students put a lot of time and effort into their studies, doing it because they wanted to achieve their goals, and because they were receiving the academic rewards of good marks.

The students reported that they did require the assistance of the Centre for Special Services and accommodations from professors (see Table 2). The most frequently used services were extended time on exams for reasons of fatigue (medical disability), slow processing and/or reading (learning disability, visual impairment). Others requested a notetaker due to absences (medical disability), inability to copy quickly (physical disability, learning disability), inability to hear all of the words, or to see the acetates or board work (hearing impairment, visual impairment). The note-takers ensured that these students had good notes from which to study. A third important accommodation requested by Special Services is a quiet room for exams. One person with a medical disability would rest periodically during the exam when he became fatigued. Others just preferred to write their exams alone.

Individual professors also provided such accommodations for the students such as extensions on assignments, alternate means of evaluation, placing the mandatory readings on tape, mid-term delays, using the FM system, and permitting the student to tape the lecture (see Table 2). One student wrote, "Professors can't help enough. All I have to do is let them know my problems and they are happy to help." However, not all of the students had professors who would make adaptations. A man with a medical disability explained that he had requested a take-home exam because he is easily fatigued. Although he had letters from his physicians, the professor refused his request. A woman with a learning disability commented that "occasionally a prof will state at the time the 
Table 2

Academic Accommodations $(n=36)$

\begin{tabular}{|c|c|c|c|c|c|c|c|}
\hline & \begin{tabular}{|c|} 
Medical \\
Disability
\end{tabular} & $\begin{array}{c}\text { Learning } \\
\text { Disability }\end{array}$ & $\begin{array}{l}\text { Physical } \\
\text { Disability }\end{array}$ & $\begin{array}{c}\text { Hearing } \\
\text { Impairment }\end{array}$ & $\begin{array}{c}\text { Visual } \\
\text { Impairment }\end{array}$ & $\begin{array}{c}\text { Multiple } \\
\text { Disabilities }\end{array}$ & Total \\
\hline \multicolumn{8}{|l|}{$\begin{array}{l}\text { Special } \\
\text { Services }\end{array}$} \\
\hline $\begin{array}{l}\text { More time } \\
\text { on exams }\end{array}$ & 8 & 4 & & & 2 & 1 & 15 \\
\hline $\begin{array}{l}\text { Quiet room } \\
\text { for exams }\end{array}$ & 5 & 2 & 1 & 1 & 2 & & 11 \\
\hline Notetaker & 6 & 2 & 1 & 2 & 1 & & 12 \\
\hline Tutor & 7 & 4 & & & & & 11 \\
\hline Taped texts & & 1 & & & & 1 & 2 \\
\hline FM system & & & & 2 & & & 2 \\
\hline $\begin{array}{l}\text { Enlarged } \\
\text { print, braille }\end{array}$ & & & & & 4 & 1 & 5 \\
\hline Other & & 1 & & & 5 & & 6 \\
\hline Professors & & & & & & & \\
\hline $\begin{array}{l}\text { More time for } \\
\text { assignments }\end{array}$ & & 2 & & & 3 & & 5 \\
\hline $\begin{array}{l}\text { Alternate } \\
\text { evaluation }\end{array}$ & 3 & & 1 & & 1 & & 5 \\
\hline $\begin{array}{l}\text { Request } \\
\text { readings } \\
\text { on tape }\end{array}$ & & 1 & & & 1 & & 2 \\
\hline Other & & 1 & & 1 & 1 & & 3 \\
\hline
\end{tabular}

assignment is handed out that 'absolutely no lates or extensions'. So unforgiving." While most professors were willing to make adaptations, most of the students had encountered at least one who was not willing to show any flexibility. 


\section{Social Integration}

Most students indicated that they felt comfortable in the social milieu of the university. The most frequent type of social contact reported was having coffee with other students. A few students stated that they socialized with their peers during the evenings and weekends, and only one indicated that she participated in intramural and varsity sports activities. Some expressed lack of time to socialize, and the need to spend all their time on academics or with their families. However others had developed their own network of social contacts outside of school. Only two students reported that they did not feel comfortable on a social level. In both cases, their sense of isolation was related to their disability. One had a medical disability and did not want other students to know about it. She said, "I won't call someone because I feel they can't relate to my experience, which may not be true. But I'll think that." Another student was blind and stated that she would like to meet people, but that it was "difficult to do this when you can't read the notices about social events." She too was shy about calling other people.

All of the students had their own sources of support. The most frequently cited sources were family, friends, and professors (see Table 3). Family and friends helped the students with their domestic duties and supported them during times when they felt discouraged about their studies. The students also cited professors as providing moral and academic support for them.

\section{Dropping out vs. Persisting}

When asked if they had ever considered dropping out, four of the 17 people participating in the individual interviews replied negatively. However, most became discouraged when their medical condition made studying, doing assignments, or attending class difficult. Others contemplated dropping out when a request was denied by the administration or a professor, or when they received a poor mark on an assignment or exam. One woman said, "It gets frustrating and stuff. But you know, you have a goal to achieve. My goal is to get my education." Two students had actually dropped out of university, but both returned to achieve their goal of graduating. One woman did leave for a year during her undergraduate 
Table 3

Sources of Support $(n=36)$

\begin{tabular}{|c|c|c|c|c|c|c|c|}
\hline & $\begin{array}{c}\text { Medical } \\
\text { Disability }\end{array}$ & $\begin{array}{l}\text { Learning } \\
\text { Disability }\end{array}$ & $\begin{array}{l}\text { Physical } \\
\text { Disability }\end{array}$ & $\begin{array}{l}\text { Hearing } \\
\text { Impairment }\end{array}$ & $\begin{array}{c}\text { Visual } \\
\text { Impairment }\end{array}$ & $\begin{array}{c}\text { Multiple } \\
\text { Disabilities }\end{array}$ & Total \\
\hline People & & & & & & & \\
\hline Family & 12 & 8 & 2 & 3 & 3 & 1 & 29 \\
\hline Friends & 12 & 6 & 1 & 3 & 2 & 2 & 26 \\
\hline Professors & 10 & 7 & & & 1 & 2 & 20 \\
\hline Medical & 9 & 1 & & & & & 10 \\
\hline $\begin{array}{l}\text { Special } \\
\text { Services }\end{array}$ & 4 & 2 & & & 3 & & 9 \\
\hline Tutors & & 2 & & & & & 2 \\
\hline \multicolumn{8}{|l|}{ Other } \\
\hline $\begin{array}{l}\text { Personal } \\
\text { Qualities }\end{array}$ & 4 & & & & 1 & 1 & 6 \\
\hline $\begin{array}{l}\text { Social \& } \\
\text { Gov't } \\
\text { Agencies }\end{array}$ & 2 & & 1 & & 2 & & 5 \\
\hline Faith & 3 & & & 1 & & & 4 \\
\hline Medication & 3 & & & & & & 3 \\
\hline Technology & 2 & & & & 1 & & 3 \\
\hline Success & 1 & & 1 & & 1 & & 3 \\
\hline Fate & 2 & & & & & & 2 \\
\hline
\end{tabular}

program to work, and the second transferred to another university when the first one failed to accommodate her needs for adaptations to exams. However, in both cases these people remained committed to their goal of a university degree and did not entirely abandon their studies. 


\section{DISCUSSION AND CONCLUSIONS}

Tinto's (1975) theory of dropout provided the theoretical framework for this study of university students with disabilities. He posits that individual characteristics influence a student's academic and social integration into the post secondary community, which, in turn, is related to dropping out or persisting behaviours. The purpose of this study was to examine the experiences of students with disabilities using Tinto's model, which would provide insight into their reasons for persisting or dropping out. Tinto's first variable is the background and characteristics of the students. The students varied in terms of disability, gender, socio-economic class, and racial and ethnic origin. Tinto (1982) states that those students closer to the completion of their program are more likely to persist than others just beginning their studies. However, the students in the present study were at various stages in their academic programs. In the literature, the nature of the secondary school programs followed by students with disabilities is viewed as important in relation to their success in higher education (Brinckerhoff, 1996; Durlak, Rose \& Bursuck, 1994; Siperstein, 1988; Vogel \& Adelman, 1992). It is recommended that students with disabilities should take advanced-level high school courses rather than remedial courses, particularly in English and Math to prepare themselves for postsecondary studies (Brinckerhoff, 1996; Durlack et al., 1994; Vogel \& Adelman, 1992). In this study, most of the students took the regular university-bound programs in high school, and they felt comfortable completing the academic requirements. Only one student did not follow an advanced secondary school program. She has a learning disability and was placed in a vocational school. Although she felt that she was intellectually capable of studying at a university, her high school program did nothing to prepare her for the requirements of postsecondary course work. Hence, she required more academic support than the others in order to pass her courses.

Another dimension of students' individual characteristics is their goal commitment, which is described in terms of plans and persistence (Tinto, 1975). The students in this study all reported that they viewed obtaining a degree as very important, and that they possessed the personal traits that 
would support the achievement of this goal. For students with disabilities the qualities of self-discipline, self-drive, goal commitment, and selfdetermination are viewed as critical for academic success (Dalke \& Schmitt, 1987; Durlak et al., 1994; Penn \& Dudley, 1980; Ward, 1988). Students with disabilities perceive postsecondary education as a means to independence and financial security (Penn \& Dudley, 1980). Hence a university degree is an important step towards a career, as well as to financial security and independence (McLoughlin, 1982, Penn \& Dudley, 1980; Wiseman, Emry \& Morgan, 1988). Most of the students in this study were preparing themselves for a career; however, a few were taking the courses for personal enrichment.

Tinto's (1975) second variable is academic integration, which relates to the students' grade performance and their intellectual development. In the literature it is argued that post secondary institutions should provide services for students with disabilities that strengthen coping skills and ensure educational support and accommodations (Barbaro, Christman, Holzinger \& Rosenberg, 1985). Most of the students in this study made use of the services and equipment provided by the Centre for Special Services. The importance of students with disabilities engagin in such practices is also reported by Brinckerfoff (1996), Dalke and Schmitt (1987), McGuire and O'Donnell (1989), McGuire, Hall and Litt (1991), Satcher and Adamson (1995), and Vogel (1982). These students also commented that they invest considerable time and effort into their studies, and were satisfied with their marks. Not surprisingly, most of the students reported feeling comfortable in the academic milieu of the university.

A second source of academic support which affected the students' level of integration into the academic milieu was the professors. The students in this study had encountered those who were empathetic and willing to make adaptations. However, most had also worked under professors who rigidly set the conditions for evaluation of course work. Kopp, Miller and Mulkey (1984) report that professors are sometimes unwilling to help because they view the student with a disability as lazy or unmotivated. Hence the attitudes of professors can present a formidable barrier to students with disabilities (Altman, 1981; Cox \& Klas, 1996; Haehl, 1989; Siperstein, 1988). 
The final variable related to dropping out or persisting is social integration (Tinto, 1975). In this study the students did not report high levels of involvement in university-based extracurricular activities or of social activity with their peers. They did have friends, and frequently reported that they went for coffee or studied with them. However, their social life was not dependent on the activities organized by the University. Most relied on their families and friends outside of class to provide recreation and moral support. In the literature, development of a social niche and support system to enhance their feelings of social connectedness is viewed as important that students with a disability develop (Dalke \& Schmitt, 1987; Penn \& Dudley, 1980; Satcher \& Adamson, 1995). Hence, these students were successful in developing support networks, although they displayed a low level of integration into a campus-based social milieu.

The results of this study on university students with disabilities support two of Tinto's (1975) variables that relate to dropping out: background characteristics and academic integration. Although the personal situations of the participants varied, all but one student had academic backgrounds that prepared them for their postsecondary studies. All reported possessing specific personality traits related to academic success. Moreover, the participants accessed academic support systems, directed time and effort toward their studies, were satisfied with their marks, and felt comfortable in the academic environment. However, these students with disabilities tended neither to socialize with university friends nor to be involved in activities organized by the institution. Instead, they mixed with members of their families and friends who were not in their classes. In summary, the findings of this study provide partial support for Tinto's (1975) model of dropout. The importance of two variables, background characteristics and academic integration, was greater than that of social integration in relation to the decision by students with disabilities to persist. However, it is important to note, that the majority of the participants in this study were female, and that all of the subjects had registered with the Centre for Special Services. Hence, it is possible that the findings might have been different if the sample 
had included a higher proportion of males and as well as students with disabilities who had not registered at the Centre for Special Services.

Three important themes not found in the theoretical framework emerged from the findings. The first theme was goal commitment. The participants were all were driven to obtain a university degree. Even those two people who dropped out returned to complete their program. All of these students believed in themselves and knew what they needed to maximize their learning. If they required specific services to help them learn the material (e.g., a tutor) or equipment (e.g., an FM system), they felt comfortable making their requests to the Centre for Special Services. However, when they needed more time to complete an assignment or write an exam, they had to ask the professor. This was not always a pleasant task.

The second theme was the importance of the professors acting as facilitators or barriers to the academic and social integration of the students. The students reported that, for the most part, professors provided accommodations and moral support for them. For some, such a stance was critical to their success. Students were thankful for flexible and empathetic professors who made adaptations to assignments and exams in terms of form or length of time required to complete the task. In the opinion of one student, "It's important to meet the individual needs of the person." On the other hand, professor attitudes and lack of understanding also present barriers to students with disabilities (Altman, 1981, Cox \& Klas, 1996). Most of the students in this study stated that they had encountered professors who refused to make accommodations for fear of lowering standards or of giving the students with disabilities an unfair advantage. It is unlikely that these professors understood the extent to which a disability might affect a person's ability to work on an assignment or write an exam. They failed to realize that some students' medical conditions prevented them from getting out of bed due to the intense pain, or that a blind person cannot go to the library and research a topic without having access to documents in alternative formats (e.g., tape, diskette), or that a person with a learning disability may not be able to read the text or exam questions as quickly as others. Such professors also do not realize that their negative attitudes and responses have the effect of limiting or 
constraining the potential achievement of students with disabilities. For some, the result is a sense of discouragement and thoughts of dropping out. However, other professors do understand that students with disabilities need support and not barriers. They also realize that an accommodation or adaptation merely provides a level field in which to begin the work. An accommodation does not represent an unfair advantage in terms of the students' completion of course work.

The third theme was the importance of the moral support from family and friends, particularly when the students felt discouraged about their studies. Such support usually came when an assignment or exam was returned with a mark that was lower than expected. For students with disabilities it also occurred when they made requests for extra time from professors, and were rejected. A young woman commented, "A day can make a big difference." All of the students reported at least one person who was able to provide the moral support required to sharpen the desire to succeed when it had become blunted by a professor who would not grant an extension.

This study describes the experiences of university students with disabilities. It shows how university students with disabilities bring with them intellectual abilities and a strong desire to succeed. While at university they engage themselves in the content of the program. For some, the course work itself is a barrier and assistance is required in reading or understanding the printed word. However, for others text-based resources are not a problem. A potential second barrier expressed by the students involves the negative attitudes of some professors towards granting extensions and other accommodations to students with disabilities. In some cases these students' achievement is dependent on the attitudes of the professors. The professors may be flexible and act as facilitators or they may have a negative attitude, thus presenting another barrier to this group of students. These people have persisted because they are goal-oriented and because of the academic support they receive from Special Services and some professors. They also have not dropped out because they are buoyed by the moral support from family and friends.

The importance of professors who instruct students with disabilities emerges as a key factor from this study. In the literature, faculty training 
focused on giving information about disabilities, improving communication with students who have disabilities, and providing suggestions for making appropriate accommodations is recommended (Haehl, 1989; Scott, 1994; Wiseman, Emry \& Morgan, 1988). The results of this study clearly support that recommendation as a means of educating professors and moving towards changing the negative attitudes of some. Welltrained professors will help make students with disabilities feel more secure and confident in the academic milieu, and enable them to experience their university education in more positive ways.

\section{References}

Altman, B. (1981). Studies of attitudes toward the handicapped: The need for a new direction. Social Problems, 28(3), 321-337.

Barbaro, F., Christman, D., Holzinger, S., \& Rosenberg, E. (1985). Support services for the learning-disabled college student. Social Work, 30(1), 12-18.

Brinckerhoff, L. (1996). Making the transition to higher education: Opportunities for student empowerment. Journal of Learning Disabilities, 29(2), 118-136.

Cox, D., \& Klas , L. (1996). Students with learning disabilities in Canadian colleges and universities: A primer for service provision. Journal of Learning Disabilities, 29(1), 93-97.

Dalke, C., \& Schmitt, S. (1987). Meeting the transition needs of collegebound students with learning disabilities. Journal of Learning Disabilities, 20(3), 176-180.

Durlak, C. Rose, E., \& Bursuck, W. (1994). Preparing high school students with learning disabilities for the transition to postsecondary education: Teaching the skills of self-determination. Journal of Learning Disabilities, 27(1), 51-59.

Haehl, S. (1989). Meeting the needs of the learning disabled college student. Journal of Reading, 33(2), 146-147.

Hill, J. (1992). Accessibility: Students with disabilities in universities in Canada. The Canadian Journal of Higher Education, 22(1), 48-83.

Kopp, K., Miller, J., \& Mulkey, S. (1984). The paradox of learning disabilities: A stumbling block to rehabilitation. Journal of Rehabilitation, 2(1), 4-5.

LeCompte, M., \& Preissle, J. (1993). Ethnography and qualitative design in educational research. Toronto, ON: Academic Press. 
Lincoln, Y., \& Guba, E. (1985). Naturalistic inquiry. Beverly Hills, CA: Sage Publications Inc.

McGuire, J., Hall, D., \& Litt, A. (1991). A field-based study of the direct service needs of college students with learning disabilities. Journal of College Student Development, 32(2), 101-108.

McGuire, J., \& O'Donnell, J. (1989). Helping learning-disabled students to achieve: Collaboration between the faculty and support services. College Teaching, 37(1), 29-32.

McKeown, B., MacDonell, A., \& Bowman, C. (1993). The point of view of the student in attrition research. The Canadian Journal of Higher Education, $23(2), 65-85$.

McLoughlin, W. (1982). Helping the physically handicapped in higher education. Journal of College Student Personnel, 30, 240-246.

Miles, M., \& Huberman, M. (1984). Qualitative data analysis: A sourcebook of new methods. Newbury Park, CA: Sage.

Morgan, D. (1988). Focus groups as qualitative research. Newbury Park, CA: Sage.

Penn, J., \& Dudley, D. (1980). The handicapped student: Problems and perceptions. Journal of College Student Personnel, 21(4), 354-357.

Satcher, J., \& Adamson, K. (1995). College students with learning disabilities: Their use of support services, accommodations and study skills. College Student Affairs Journal, 14(2), 83-90.

Scott, S. (1994). Determining reasonable academic adjustments for college students with learning disabilities. Journal of Learning Disabilities, 27(7), $403-412$.

Siperstein, G. (1988). Students with learning disabilities in college: The need for aprogrammatic approach to critical transitions. Journal of Learning Disabilities, 21(7), 431-436.

Tinto, V. (1975). Dropout from higher education: A theoretical synthesis of recent research. Review of Educational Research. 45(1), 89-125.

Tinto, V. (1982). Limits of theory and practice in student attrition. Journal of Higher Education, 53(6), 687-700.

Vogel, S. (1982). On developing LD college programs. Journal of Learning Disabilities, 15(9), 518-528.

Vogel, S., \& Adelman, P. (1992). The success of college students with learning disabilities: Factors related to educational attainment. Journal of Learning Disabilities, 25(7), 430-441. 
Wilchesky, M. (1986). Postsecondary programs and services for exceptional persons: NorthAmerican trends. Paper presentation at the Canadian Symposium on Special Education Issues, Toronto, ON, March 4-5, 1986.

Wiseman, R., Emry, R., \& Morgan, D. (1988). Predicting academic success for disabled students in higher education. Research in Higher Education, 28(3), 255-269. 